\title{
ANALISIS PREDIKSI KEBANGKRUTAN PADA INDUSTRI OTOMOTIF
}

\author{
Ade Irma Suryani ${ }^{1}$ \\ Dosen Tetap Universitas Muhammadiyah Jambi ${ }^{1}$ \\ adeirma.utama@gmail.com \\ Rahmi Handayani ${ }^{2}$ \\ Dosen Tetap Universitas Muhammadiyah Jambi² \\ Handayani.rahmi@gmail.com
}

\section{Ringkasan}

Penelitian ini bertujuan untuk menganalisis kondisi perusahaan menggunakan metode Altman Z-Score dalam memprediksi potensi kebangkrutan pada 12 perusahaan otomotif yang terdaftar di Bursa Efek Indonesia tahun 2015 - 2018. Pengambilan sampel menggunakan teknik purposive sampling dan diperoleh sampel sebanyak 8 perusahaan otomotif.

Pertumbuhan penjualan dan asset yang dimiliki perusahaan otomotif yang terdaftar di Bursa Efek Indonesia pada tahun 2015 - 2018, menunjukan tiga perusahaan yakni PT Astra Otoparts Tbk, PT Indo Kordsa Tbk dan PT Selamat Sempurna Tbk selalu mengalami peningkatan pada penjualannya dan tiga perusahaan yakni PT Astra International Tbk, PT Astra Otoparts Tbk dan PT Indomobil Sukses Internasional Tbk selalu mengalami peningkatan pada assetnya. Sedangkan untuk perusahaan lainnya mengalami fluktuasi dalam penjualan dan assetnya.

Hasil dari analisis kebangkrutan mengunakan metode Altman (Z-Score) pada tahun 2015 sampai dengan 2018 menunjukkan perusahaan PT Selamat Sempurna Tbk sebagai perusahaan satu-satunya diantara perusahaan otomoyif lainnya yang berada dalam kategori baik atau sehat, karena ditinjau dari nilai Z-Score yang diperoleh PT Selamat Sempurna Tbk menunjukkan hasil melebihi standar (Z-Score $>2$ 299) serta tidak ada nilai rasio yang bernilai negatif, hal ini menunjukkan kinerja keuangan perusahaan tersebut baik. PT Goodyear Indonesia Tbk dan PT Indomobil Sukses Internasional Tbk berada dalam kategori rawan (grey area)dimana perusahaan tersebut tidak dapat ditentukan apakah termasuk perusahaan yang bangkrut atau tidak, namun memiliki potensi kebangkrutan, karena ditinjau dari nilai Z-Score perusahaan menunjukkan hasil 1,81 < Z-Score < 2,99. PT Astra Otoparts Tbk, PT Multistrada Arah Sarana Tbk dan PT Prima Alloy Steel Universal Tbk dikategorikan sebagai perusahaan yang memiliki kesulitan keuangan yang sangat besar dan berisiko bangkrut, karena ditinjau dari nilai Z-Score perusahaan menunjukkan hasil Z-Score $<1,81$. PT Astra International Tbk dan PT Indo Kordsa Tbk dikategorikan rawan dam perusahaan memiliki kesulitan keuangan yang sangat besar dan berisiko bangkrut.

Kata Kunci : Perusahaan Otomotif, Kebangkrutan, Altman Z-Score

\section{PENDAHULUAN}

Persaingan perusahaan yang semakin ketat di era globalisasi ini menuntut perusahaan untuk berusaha lebih kuat dalam mempertahankan keberlangsungan usahanya dengan berbagai strategi yang telah dirancang untuk tetap mempertahankan konsumen sebagai pendapatan. Ketatnya persaingan mengharuskan perusahaan harus ekstra kerja keras melakukan 
pengelolaan manajemen dengan baik, manajemen perusahaan perlu menentukan strategi untuk menghadapi segala tantangan dan persaingan.

Industri otomotif telah menjadi sebuah pilar penting dalam sektor manufaktur di indonesia. Menggeliatnya sektor industri otomotif dan sektor industri lainnya secara keseluruhan sagat penting karena industri memberikan sumbangan terbesar terhadap produk domestik bruto (PDB) nasional sebesar 20 persen

Kinerja industri otomotif saat ini dinilai tergolong baik dan terus berkembang. Selama tahun 2017 investasi industry otomotif yang sudah diselesaikan mencapai Rp 16,5 triliun. Kemudian investasi tersebut telah menambah lahan 5.000 lapangan pekerjaan, dengan total pekerja dibidang industry otomotif mencapai lima juta orang. (Menperin, 2017)

Diprediksi industri otomotif juga akan terus melaju pesat, bahkan posisinya bias menjadi tulang punggung pemerintah dalam mewujudkan target pertumbuhan industri sebesar 5,67 persen bersama dengan sektor industri lainnya. Pertumbuhan industri tahun ini didorong oleh industri logam, mesin, alat transportasi, dan elektronika. Namun terlepas dari perkembangannya tersebut juga, industri otomotif diprediksi masih banyak menghadapi tantangan pada tahun 2018. Tantangan ini harus menjadi perhatian khusus bagi industri agar tidak terjebak dalam kesuliatan, baik kesulitan manajerial maupun kesulitan finansial.

Kepailitan suatu perusahaan biasanya diawali dengan kesulitan keuangan (financial distress) yang ditandai oleh adanya ketidakpastian profitabilitas pada masa yang akan datang. Prediksi tentang kondisi keuangan perusahaan, yang berkaitan dengan kepailitan, memberikan panduan bagi pihak yang berkepentingan tentang kinerja keuangan perusahaan apakah akan mengalami kesulitan atau tidak dimasa yang akan datang. Sedangkan bagi pihak yang berada diluar perusahaan khususnya para investor untuk menilai kondisi keuangan dan hasil operasi perusahaan saat ini dan dimasa lalu serta sebagai pedoman mengenai kinerja perusahaan dimana perusahaan tersebut apakah akan berpotensi untuk bangkrut atau tidak.

Analisis kebangkrutan dilakukan untuk memperoleh peringatan awal dan tanda-tanda kebangkrutan tersebut. Semakin dini kebangkrutan terdeteksi maka semakin baik pula bagi perusahaan, karena perusahaan dapat mengambil tindakan-tindakan yang seharusnya dapat diambil sebagai tindakan penyelamatan atau tindakan minimalisir atas akibat yang akan terjadi agar tidak memburuk.

Berbagai macam metode analisis kebangkrutan dari sektor keuangan telah dikembangkan dan digunakan oleh berbagai negara, salah satunya adalah metode Altman 
dengan metode Z-Score. Analisis Z-Score pertama kali dikemukakan oleh Edward I Altman pada tahun 1968 atas penelitian yang dilakukan di Amerika Serikat khusus perusahaan manufaktur yang go public. Tahun 1984 model kebangkrutan tersebut direvisi agar dapat digunakan untuk private manufacturing company dan go public. Selanjutnya pada tahun 1995 Altman memodifikasi kembali modelnya agar dapat diterapkan pada semua jenis perusahaan.

Peneliti memilih untuk menggunakan metode analisis Altman (metode Z-Score), karena metode Z-Score mudah digunakan serta mampu memperoleh tingkat ketepatan prediksi hingga 95\%. Adapun beberapa tujuan yang akan diteliti dalam penelitian ini adalah:

1. Untuk mengetahui pertumbuhan penjualan dan asset yang dimiliki perusahaan otomotif yang terdaftar di Bursa Efek Indonesia pada tahun 2015 - 2018.

2. Untuk mengetahui besarnya rasio Altman Z-Score pada perusahaan otomotif yang terdaftar di Bursa Efek Indonesia pada tahun 2015 - 2018.

3. Untuk mengetahui prediksi potensi kebangkrutan dengan menggunakan metode Altman ZScore pada perusahaan otomotif yang terdaftar di Bursa Efek Indonesia pada tahun 2015 2018.

\section{METODOLOGI}

\section{Objek Penelitian}

Dalam penelitian ini yang menjadi objek penelitian adalah 12 perusahaan aktif yang selalu tergabung dalam daftar perusahaan otomotif di Bursa Efek Indonesia (BEI) yang secara rutin menyajikan data lengkap dan mempublikasikan laporan keuangan secara berturut-turut dari tahun $2014-2017$.

Daftar 12 perusahaan tersebut adalah : (1) Astra International Tbk, (2) Astra Otoparts Tbk, (3) Indo Kordsa Tbk, (4) Goodyear Indonesia Tbk, (5) Gajah Tunggal Tbk, (6) Indomobil Sukses Internasional Tbk, (7) Indospring Tbk, (8) Multi Prima Sejahtera Tbk, (9) Multistrada Arah Sarana Tbk, (10) Nipress Tbk, (11) Prima Alloy Steel Universal Tbk, dan (12) Selamat Sempurna Tbk.

\section{Jenis dan Sumber Data Penelitian}

Jenis data yang digunakan merupakan data sekunder, yaitu data yang diperoleh dari perusahaan yang merupakan hasil olahan pihak lain. Data dapat diperoleh dari berbagai sumber antara lain Bursa Efek Indonesia (www.idx.co.id) dan literature-literatur yang berkaitan dengan penelitian ini. Adapun data-data tersebut berupa : 
1. Data Kuantitatif, yaitu data yang dapat dihitung atau berupa angka-angka. Dalam penelitian ini berupa data laporan keuangan untuk masing-masing perusahaan otomotif, jenis laporan keuangan yang digunakan adalah neraca keuangan dan laporan laba rugi dari masingmasing perusahaan otomotif.

2. Data Kualitatif, yaitu data yang tidak dapat dihitung atau data yang bersifat non angka, antara laian sejarah singkat perusahaan dan struktur organisasi perusahaan.

\section{Teknik Analisis Data}

Teknik yang digunakan untuk menganalisis data adalah dengan mengumpulkan 5 variabel yaitu Modal Kerja terhadap Total aktiva (Working Capital to Total Assets), Laba Ditahan terhadap Total Aktiva (Reaned Earning to Total Assets), Laba Sebelum Bunga dan Pajak terhadap Total Aktiva (Earing Before Interest and Taxes to Total Assets), Nilai Pasar Saham Biasa dan Preferen terhadap Nilai Buku Total Hutang (Market Value of Equity to Book Value of Total Liabilities), dan Penjualan terhadap Total Aktiva (Sales to Total Assets).

\section{Alat Analisis Data}

Dalam penelitian ini, data yang diperoleh akan dianalisis dengan menggunakan alat analisis, yaitu :

1. Analisis Trend Horizontal, yaitu alat analisis yang digunakan untuk membandingkan masing-masing variable dari tahun ketahun secara keseluruhan (time series). Analisis ini dimaksudkan untuk mengetahui perkembangan atau perubahan setiap masing-masing variable pada perusahaan-perusahaan otomotif. Formulasi yang digunakan untuk mengetahui perkembangan adalah sebagai berikut :

Perkembangan $=\frac{D_{t}-D_{t-1}}{D_{t-1}} \times 100 \%$

Keterangan : $\quad \mathrm{D}_{\mathrm{t}} \quad=$ Data tahun yang dianalisis

$\mathrm{D}_{\mathrm{t}-1} \quad=$ Data tahun sebelumnya

2. Modal Kerja terhadap Total aktiva (Working Capital to Total Assets)

$\mathrm{X}_{1}=\frac{\text { Aktiva Lancar-Hutang LAncar }}{\text { Total Aktiva }}$

Variable ini digunakan untuk mengukur kemampuan perusahaan dalam memenuhi kewajiban jangka pendeknya dan untuk mengukur tingkat likuiditas aktiva perusahaan. Sebuah modal kerja yang bernilai positif menunjukkan kemampuan perusahaan untuk membayar tagihannya sedangkan apabila sebuah perusahaan memiliki modal yang bernilai negatif maka perusahaan tersebut akan mengalami kesulitan dalam memenuhi kewajibannya. 
3. Laba Ditahan terhadap Total Aktiva (Reaned Earning to Total Assets)

$\mathrm{X}_{2}=\frac{\text { Laba Bersih }}{\text { Total Ekuitas }} \mathrm{X} 100 \%$

Variabel $\mathrm{X}_{2}$ merupakan rasio profitabilitas untuk mengukur pengembalian yang diperoleh pemilik atas investasi di perusahaan.

4. Laba Sebelum Bunga dan Pajak terhadap Total Aktiva (Earing Before Interest and Taxes to Total Assets)

$\mathrm{X}_{3}=\frac{\text { Laba Sebelum Bunga dan Pajak }}{\text { Total Aktiva }}$

Variabel $\mathrm{X}_{3}$ yang termasuk dalam rasio profitabilitas ini memiliki fungsi untuk mengukur kemampuan perusahaan dalam menghasilkan laba dari aktiva yang digunakan atau dapat dikatakan sebagai ukuran produktivitas aset perusahaan.

5. Total Hutang terhadap Ekuitas (Equity)

$\mathrm{X}_{4}=\frac{\text { Total Hutang }}{\text { Ekuitas }}$

Variabel $\mathrm{X}_{4}$ ini digunakan untuk menilai utang dengan ekuitas. Rasio ini berguna untuk mengetahui dana yang disediakan peminjam (kreditor) dengan pemilik perusahaan. Bagi perusahaan, semakin tinggi rasio ini akan semakin tinggi resiko keuangan perusahaan tersebut.

6. Penjualan terhadap Total Aktiva (Sales to Total Assets)

$\mathrm{X}_{5}=\frac{\text { Penjualan }}{\text { Total Aktiva }}$

Variabel $\mathrm{X}_{5}$ berfungsi untuk mengukur kemampuan manajemen dalam menggunakan aktiva untuk menghasilkan penjualan dan menggambarkan tingkat perputaran seluruh aktiva perusahaan.

\section{HASIL PENELITIAN}

\section{Pertumbuhan Penjualan dan Asset Perusahaan Otomotif Pada Tahun 2015 - 2018}

Laporan keuangan berisikan data-data keuangan atau kinerja perusahaan dalam satu periode atau satu tahun. Berdasarkan rumusan masalah penelitian pada bab sebelumya maka, data keuangan perusahaan otomotif diolah untuk mendapatkan dan melihat bagaimana pertumbuhan penjualan, pertumbuhan asset, dan mengetahui besarnya rasio Altman Z-Score serta mengetahui prediksi potensi kebangkrutan perusahaan-perusahaan otomotif yang terdaftar di Bursa Efek Indonesia pada tahun 2015 - 2018. 
Tabel.1 Pertumbuhan Penjualan Perusahaan Otomotif Pada Tahun 2016 - 2018

\begin{tabular}{|l|c|r|r|r|}
\hline \multirow{2}{*}{ Nama Perusahaan } & \multirow{2}{*}{\begin{tabular}{c} 
Kode \\
\cline { 3 - 5 }
\end{tabular}} & \multicolumn{3}{c|}{ Perusahaan } \\
\cline { 3 - 5 } & ASII & $\mathbf{2 0 1 6}$ & $\mathbf{2 0 1 7}$ & $\mathbf{2 0 1 8}$ \\
\hline Astra International Tbk & AUTO & $(0.02)$ & 0.14 & 0.16 \\
\hline Astra Otoparts Tbk & BRAM & 0.09 & 0.06 & 0.13 \\
\hline Indo Kordsa Tbk & GDYR & 0.06 & 0.10 & 0.09 \\
\hline Goodyear Indonesia Tbk & IMAS & $(0.00)$ & 0.04 & $(0.01)$ \\
\hline Indomobil Sukses Internasional Tbk & MASA & $(0.03)$ & 0.02 & 0.14 \\
\hline Multistrada Arah Sarana Tbk & PRAS & $(0.22)$ & 0.22 & 0.08 \\
\hline Prima Alloy Steel Universal Tbk & SMSM & 0.03 & $0.05)$ & 0.65 \\
\hline Selamat Sempurna Tbk & & & 0.16 & 0.18 \\
\hline
\end{tabular}

Sumber : idx.co.id (data diolah)

Berdasarkan table.1 pertumbuhan penjualan perusahaan otomotif menunjukan terdapat tiga perusahaan yakni PT Astra Otoparts Tbk, PT Indo Kordsa Tbk dan PT Selamat Sempurna Tbk selalu mengalami peningkatan pada penjualannya. Sedangkan untuk perusahaan lainnya mengalami fluktuasi dalam penjualannya.

Tabel.2 Pertumbuhan Asset Perusahaan Otomotif Pada Tahun 2016 - 2018

\begin{tabular}{|c|c|c|c|c|}
\hline \multirow{2}{*}{ Nama Perusahaan } & \multirow{2}{*}{\begin{tabular}{|c|} 
Kode \\
Perusahaan
\end{tabular}} & \multicolumn{3}{|c|}{ Pertumbuhan Asset (\%) } \\
\hline & & 2016 & 2017 & 2018 \\
\hline Astra International Tbk & ASII & 0.07 & 0.13 & 0.17 \\
\hline Astra Otoparts Tbk & AUTO & 0.02 & 0.01 & 0.08 \\
\hline Indo Kordsa Tbk & BRAM & 0.01 & 0.03 & $(0.03)$ \\
\hline Goodyear Indonesia Tbk & GDYR & $(0.05)$ & 0.10 & 0.02 \\
\hline Indomobil Sukses Internasional Tbk & IMAS & 0.03 & 0.23 & 0.30 \\
\hline Multistrada Arah Sarana Tbk & MASA & 0.02 & 0.08 & $(0.02)$ \\
\hline Prima Alloy Steel Universal Tbk & PRAS & $(0.41)$ & 0.70 & 0.06 \\
\hline Selamat Sempurna Tbk & SMSM & $(0.48)$ & 1.12 & 0.15 \\
\hline
\end{tabular}

\section{Sumber : idx.co.id (data diolah)}

Berdasarkan table.2 pertumbuhan asset perusahaan otomotif menunjukan terdapat tiga perusahaan yakni PT Astra International Tbk, PT Astra Otoparts Tbk dan PT Indomobil Sukses Internasional Tbk selalu mengalami peningkatan pada assetnya. Sedangkan untuk perusahaan lainnya mengalami fluktuasi atas asset yang dimilikinya.

\section{Hasil Perhitungan dan Analisis Rasio Altman Z-score}

Tabel.3 Hasil Perhitungan Altman Z-Score pada tahun 2015

\begin{tabular}{|c|c|c|c|c|c|c|c|c|}
\hline No. & Nama Perusahaan & Kode Perusahaan & $1.2 \times 1$ & $1.4 \times 2$ & $3.3 \times 3$ & $0.6 \times 4$ & $1.0 \times 5$ & Z-Score \\
\hline 1 & Astra International Tbk & ASII & 0.14 & 0.17 & 0.26 & 0.56 & 0.75 & 1.89 \\
\hline 2 & Astra Otoparts Tbk & AUTO & 0.10 & 0.04 & 0.10 & 0.25 & 0.82 & 1.30 \\
\hline 3 & Indo Kordsa Tbk & BRAM & 0.19 & 0.10 & 0.21 & 0.36 & 0.71 & 1.56 \\
\hline 4 & Goodyear Indonesia Tbk & GDYR & $(0.11)$ & $(0.00)$ & 0.04 & 0.69 & 1.30 & 1.91 \\
\hline 5 & Indomobil Sukses Internasional Tbk & IMAS & $(0.04)$ & $(0.00)$ & 0.03 & 1.63 & 0.73 & 2.34 \\
\hline 6 & Multistrada Arah Sarana Tbk & MASA & 0.07 & $(0.11)$ & $(0.15)$ & 0.44 & 0.40 & 0.65 \\
\hline 7 & Prima Alloy Steel Universal Tbk & PRAS & 0.00 & 0.01 & 0.02 & 0.67 & 0.31 & 1.01 \\
\hline 8 & Selamat Sempurna Tbk & SMSM & 0.43 & 0.45 & 0.87 & 0.32 & 1.26 & 3.33 \\
\hline
\end{tabular}


Berdasarkan tabel.3 hasil perhitungan di atas menunjukkan bahwa terdapat satu perusahaan yakni PT Selamat Sempurna Tbk berada pada kondisi keuangan yang baik atau sehat $(Z>2,99)$. PT Selamat Sempurna Tbk memiliki nilai Z-Score tertinggi dan bernilai lebih dari 2,99 yaitu 3,33. Hasil perhitungan di atas juga menunjukkan bahwa terdapat tiga perusahaan yakni PT Astra International Tbk, PT Goodyear Indonesia Tbk dan PT Indomobil Sukses Internasional Tbk berada di daerah rawan (grey area) dimana perusahaan tersebut tidak dapat ditentukan apakah termasuk perusahaan yang bangkrut atau tidak, namun memiliki potensi kebangkrutan dan empat perusahaan yakni PT Astra Otoparts Tbk, PT Indo Kordsa Tbk, PT Multistrada Arah Sarana Tbk dan PT Prima Alloy Steel Universal Tbk dikategorikan sebagai perusahaan yang memiliki kesulitan keuangan yang sangat besar dan berisiko bangkrut.

Tabel.4 Hasil Perhitungan Rasio Altman Z-Score pada tahun 2016

\begin{tabular}{|c|c|c|c|c|c|c|c|c|}
\hline No. & Nama Perusahaan & Kode Perusahaan & $1.2 \times 1$ & $1.4 \times 2$ & $3.3 \times 3$ & $0.6 \times 4$ & $1.0 \times 5$ & Z-Score \\
\hline 1 & Astra International Tbk & ASII & 0.10 & 0.18 & 0.28 & 0.52 & 0.69 & 1.78 \\
\hline 2 & Astra Otoparts Tbk & AUTO & 0.14 & 0.07 & 0.15 & 0.23 & 0.88 & 1.46 \\
\hline 3 & Indo Kordsa Tbk & BRAM & 0.22 & 0.16 & 0.35 & 0.30 & 0.74 & 1.76 \\
\hline 4 & Goodyear Indonesia Tbk & GDYR & $(0.08)$ & 0.04 & 0.08 & 0.60 & 1.37 & 2.01 \\
\hline 5 & Indomobil Sukses Internasional Tbk & IMAS & $(0.04)$ & $(0.07)$ & $(0.03)$ & 1.69 & 0.59 & 2.14 \\
\hline 6 & Multistrada Arah Sarana Tbk & MASA & 0.02 & $(0.03)$ & $(0.04)$ & 0.48 & 0.38 & 0.80 \\
\hline 7 & Prima Alloy Steel Universal Tbk & PRAS & 0.01 & $(0.01)$ & 0.01 & 0.78 & 0.40 & 1.20 \\
\hline 8 & Selamat Sempurna Tbk & SMSM & 0.98 & 0.44 & 1.88 & 0.26 & 2.49 & 6.06 \\
\hline
\end{tabular}

Berdasarkan tabel.4 hasil perhitungan di atas menunjukkan bahwa PT Selamat Sempurna Tbk berada pada kondisi keuangan yang baik atau sehat $(Z>2,99)$. PT Selamat Sempurna Tbk memiliki nilai Z-Score tertinggi dan bernilai lebih dari 2,99 yaitu dengan nilai 6,06. Hasil perhitungan di atas juga menunjukkan bahwa terdapat dua perusahaan yakni PT Goodyear Indonesia Tbk dan PT Indomobil Sukses Internasional Tbk berada di daerah rawan (grey area) dimana perusahaan tersebut tidak dapat ditentukan apakah termasuk perusahaan yang bangkrut atau tidak, namun memiliki potensi kebangkrutan dan lima perusahaan yakni PT Astra International Tbk, PT Astra Otoparts Tbk, PT Indo Kordsa Tbk, PT Multistrada Arah Sarana Tbk dan PT Prima Alloy Steel Universal Tbk dikategorikan sebagai perusahaan yang memiliki kesulitan keuangan yang sangat besar dan berisiko bangkrut. 
Tabel.5 Hasil Perhitungan Rasio Altman Z-Score pada tahun 2017

\begin{tabular}{|c|c|c|c|c|c|c|c|c|}
\hline No. & Nama Perusahaan & Kode Perusahaan & $1.2 \times 1$ & $1.4 \times 2$ & $3.3 \times 3$ & $0.6 \times 4$ & $1.0 \times 5$ & Z-Score \\
\hline 1 & Astra International Tbk & ASII & 0.09 & 0.21 & 0.33 & 0.53 & 0.70 & 1.86 \\
\hline 2 & Astra Otoparts Tbk & AUTO & 0.18 & 0.07 & 0.16 & 0.22 & 0.92 & 1.55 \\
\hline 3 & Indo Kordsa Tbk & BRAM & 0.27 & 0.16 & 0.37 & 0.24 & 0.79 & 1.83 \\
\hline 4 & Goodyear Indonesia Tbk & GDYR & $(0.16)$ & $(0.02)$ & $(0.01)$ & 0.79 & 1.30 & 1.90 \\
\hline 5 & Indomobil Sukses Internasional Tbk & IMAS & $(0.10)$ & $(0.01)$ & 0.02 & 1.43 & 0.49 & 1.83 \\
\hline 6 & Multistrada Arah Sarana Tbk & MASA & $(0.02)$ & $(0.03)$ & $(0.04)$ & 0.57 & 0.43 & 0.91 \\
\hline 7 & Prima Alloy Steel Universal Tbk & PRAS & 0.00 & $(0.03)$ & 0.01 & 0.84 & 0.23 & 1.04 \\
\hline 8 & Selamat Sempurna Tbk & SMSM & 0.56 & 0.43 & 0.97 & 0.20 & 1.37 & 3.53 \\
\hline
\end{tabular}

Berdasarkan tabel.5 hasil perhitungan di atas menunjukkan bahwa terdapat satu perusahaan yakni PT Selamat Sempurna Tbk berada pada kondisi keuangan yang baik atau sehat $(Z>2,99)$. PT Selamat Sempurna Tbk memiliki nilai Z-Score tertinggi dan bernilai lebih dari 2,99 yaitu dengan nilai 3,53. Hasil perhitungan di atas juga menunjukkan bahwa empat perusahaan yakni PT Astra International Tbk, PT Indo Kordsa Tbk, PT Goodyear Indonesia Tbk dan PT Indomobil Sukses Internasional Tbk berada di daerah rawan (grey area) dimana perusahaan tersebut tidak dapat ditentukan apakah termasuk perusahaan yang bangkrut atau tidak, namun memiliki potensi kebangkrutan dan tiga perusahaan yakni PT Astra Otoparts Tbk, PT Multistrada Arah Sarana Tbk dan PT Prima Alloy Steel Universal Tbk dikategorikan sebagai perusahaan yang memiliki kesulitan keuangan yang sangat besar dan berisiko bangkrut.

Tabel.6 Hasil Perhitungan dan Analisis Metode Altman Z-Score pada tahun 2018

\begin{tabular}{|c|l|r|r|r|r|r|r|r|}
\hline No. & Nama Perusahaan & Kode Perusahaan & \multicolumn{1}{|c|}{$\mathbf{1 . 2 X 1}$} & $\mathbf{1 . 4 X 2}$ & \multicolumn{1}{|c|}{$\mathbf{3 . 3 X 3}$} & \multicolumn{1}{|c|}{$\mathbf{6 X 4}$} & \multicolumn{1}{c|}{$\mathbf{1 . 0 X 5}$} & Z-Score \\
\hline 1 & Astra International Tbk & ASII & 0.06 & 0.22 & 0.34 & 0.59 & 0.69 & 1.89 \\
\hline 2 & Astra Otoparts Tbk & AUTO & 0.15 & 0.08 & 0.18 & 0.25 & 0.97 & 1.62 \\
\hline 3 & Indo Kordsa Tbk & BRAM & 0.23 & 0.12 & 0.30 & 0.21 & 0.89 & 1.76 \\
\hline 4 & Goodyear Indonesia Tbk & GDYR & $(0.21)$ & 0.01 & 0.03 & 0.79 & 1.27 & 1.89 \\
\hline 5 & Indomobil Sukses Internasional Tbk & IMAS & 0.42 & 0.01 & 0.02 & 1.78 & 0.43 & 2.66 \\
\hline 6 & Multistrada Arah Sarana Tbk & MASA & 0.02 & $(0.04)$ & $(0.14)$ & 0.30 & 0.47 & 0.62 \\
\hline 7 & Prima Alloy Steel Universal Tbk & PRAS & $(0.10)$ & 0.01 & 0.02 & 0.75 & 0.35 & 1.04 \\
\hline 8 & Selamat Sempurna Tbk & SMSM & 0.59 & 0.41 & 0.98 & 0.18 & 1.40 & 3.57 \\
\hline
\end{tabular}

Berdasarkan tabel.6 hasil perhitungan di atas menunjukkan bahwa PT Selamat Sempurna Tbk berada pada kondisi keuangan yang baik atau sehat $(Z>2,99)$. PT Selamat Sempurna Tbk memiliki nilai Z-Score tertinggi dan bernilai lebih dari 2,99 yaitu 3,57. Hasil perhitungan di atas juga menunjukkan bahwa tiga perusahaan yakni PT Astra International Tbk, PT Goodyear Indonesia Tbk dan PT Indomobil Sukses Internasional Tbk berada di daerah rawan (grey area) dimana perusahaan tersebut tidak dapat ditentukan apakah termasuk perusahaan yang bangkrut atau tidak, namun memiliki potensi kebangkrutan dan empat perusahaan yakni PT Astra Otoparts Tbk, PT Indo Kordsa Tbk, PT Multistrada Arah Sarana 
Tbk dan PT Prima Alloy Steel Universal Tbk dikategorikan sebagai perusahaan yang memiliki kesulitan keuangan yang sangat besar dan berisiko bangkrut.

\section{KESIMPULAN}

Berdasarkan hasil analisis dari pembahasan yang telah diuraikan pada bab sebelumnya, maka dapat diambil kesimpulan sebagai berikut :

1. Pertumbuhan penjualan dan asset yang dimiliki perusahaan otomotif yang terdaftar di Bursa Efek Indonesia pada tahun 2015 - 2018, menunjukan tiga perusahaan yakni PT Astra Otoparts Tbk, PT Indo Kordsa Tbk dan PT Selamat Sempurna Tbk selalu mengalami peningkatan pada penjualannya dan tiga perusahaan yakni PT Astra International Tbk, PT Astra Otoparts Tbk dan PT Indomobil Sukses Internasional Tbk selalu mengalami peningkatan pada assetnya. Sedangkan untuk perusahaan lainnya mengalami fluktuasi dalam penjualan dan assetnya.

2. Hasil dari analisis kebangkrutan mengunakan metode Altman (Z-Score) pada tahun 2015 sampai dengan 2018 menunjukkan perusahaan PT Selamat Sempurna Tbk sebagai perusahaan satu-satunya diantara perusahaan otomoyif lainnya yang berada dalam kategori baik atau sehat, karena ditinjau dari nilai Z-Score yang diperoleh PT Selamat Sempurna Tbk menunjukkan hasil melebihi standar (Z-Score $>2,99)$ serta tidak ada nilai rasio yang bernilai negatif, hal ini menunjukkan kinerja keuangan perusahaan tersebut baik. PT Goodyear Indonesia Tbk dan PT Indomobil Sukses Internasional Tbk berada dalam kategori rawan (grey area)dimana perusahaan tersebut tidak dapat ditentukan apakah termasuk perusahaan yang bangkrut atau tidak, namun memiliki potensi kebangkrutan, karena ditinjau dari nilai Z-Score perusahaan menunjukkan hasil 1,81<Z-Score $<2,99$. PT Astra Otoparts Tbk, PT Multistrada Arah Sarana Tbk dan PT Prima Alloy Steel Universal Tbk dikategorikan sebagai perusahaan yang memiliki kesulitan keuangan yang sangat besar dan berisiko bangkrut, karena ditinjau dari nilai Z-Score perusahaan menunjukkan hasil Z-Score $<1,81$. PT Astra International Tbk dan PT Indo Kordsa Tbk dikategorikan rawan dam perusahaan memiliki kesulitan keuangan yang sangat besar dan berisiko bangkrut. 


\section{DAFTAR PUSTAKA}

Agus Sartono, 2008. Manajemen Keuangan Teori dan Aplikasi Edisi Empat, Yogyakarta: BPFE

Dewi Utari. dkk. 2014. Manajemen Keuangan : Kajian Praktik dan Teori dalam Mengelola Keuangan Organisasi Perusahaan. Jakarta : Mitra Wacana Media.

Fahmi, 2013. Analisis Laporan Keuangan. Bandung : Alfabeta.

Suad Husnan. 2008. Manajemen Keuangan: Teori dan Penerapan Buku 1,Edisi 4, Yogyakarta: BPFE.

Kasmir. 2014. Analisis Laporan Keuangan Edisi Satu. Cetakan Ketujuh. Jakarta : PT Raja Grafindo Persada.

Laporan Keuangan dan Tahunan Perusahaan Otomotif Periode Tahun 2015-2018 tersedia di: https://www.idx.co.id/perusahaan-tercatat/laporan-keuangan-dan-tahunan.

Mamduh M. Hanafi dan Abdul Halim, 2014. Analisis Laporan Keuangan. Edisi tujuh., UPP AMP YKPN, Yogyakarta.

Ma'ruf Abdullah, 2015. Metodologi Penelitian Kuantitatif. Cetakan 1. Yogyakarta: Aswaja Pressindo.

Rudianto, 2013. Akuntansi Manajemen Informasi untuk Pengambilan Keputusan Strategis. Jakarta: Erlangga.

Sofyan Syafri Harahap, 2011. Analisis Kritis Atas Laporan Keuangan. Jakarta: Raja grafindo Persada. 